\title{
What Has Athens to Do with Rome? Tocqueville and the New Republicanism
}

\author{
ALEXANDER JECH
}

\begin{abstract}
The recent debate over "republican" conceptions of freedom as non-domination has reinvigorated philosophical discussions of freedom. However, "neo-Roman" republicanism, which has been characterized as republicanism that respects equality, has largely ignored the work of Alexis de Tocqueville, although he too took his task to be crafting a republicanism suited to equality. I therefore provide a philosophical treatment of the heart of Tocqueville's republicanism, including an analysis of his conception of freedom as freedom in combined action and a philosophical reconstruction of his primary argument for the importance of this kind of freedom. A comparison of Philip Pettit's and Tocqueville's republicanism exposes limitations in the neo-Roman conception of freedom as non-domination and its ideal of the free citizen and shows why neo-Roman republicanism, to live up to its motivating ideals, should accommodate elements of "neoAthenian" republicanism and freedom in combined action.
\end{abstract}

"What is man that thou art mindful of him?" .. . The whole political, social, and economic structure of any society is largely determined by its answer to this pressing question ... whether man is a $\operatorname{cog}$ in the wheel of the state or whether he is a free creative being capable of facing responsibility. (King 1959/2001, 9)

\section{THE NEW REPUBLICANISM: FREEDOM AND EQUALITY}

Recent philosophical discussions of liberty have been enriched and reinvigorated by the reappearance of "republican" conceptions of freedom in the work

Alexander Jech is assistant professor of the practice and director of undergraduate studies, Department of Philosophy, Faculty Fellow, Nanovic Institute for European Studies, University of Notre Dame, 100 Malloy Hall, Notre Dame, IN 46556 (awjjech@gmail.com).

For helpful comments and improvements to this paper I owe gratitude to Bernie Boxill, Keegan Callanan, Roger Knights, Philip Pettit, Geoff Sayre-McCord, Susan Wolf, and Michael Zuckert.

American Political Thought: A Journal of Ideas, Institutions, and Culture, vol. 6 (Fall 2017).

2161-1580/2017/0604-0002\$10.00. @ 2017 by The Jack Miller Center. All rights reserved. 
of historians such as Quentin Skinner and philosophers such as Philip Pettit. Freedom so understood consists not in the absence of interference, constraints, or coercion, but instead in the absence of domination.

The classical republican tradition is rooted in a set of texts that elucidate and defend republican ideas and ideals (by authors such as Cicero, Polybius, Livy, the Machiavelli of The Discourses, Harrington, Milton, Sidney, etc.), as well as a series of historical regimes in which republican ideals are to a partial but significant extent embodied (such as the Roman Republic, the Florentine and Venetian city-states, the Dutch Republic, the English Commonwealth, the American Republic, and so on; Pettit 2012, 6-7). What Skinner and Pettit claim sets the new republicanism apart from the classical variety is a commitment to equality; their version aims to provide liberty for all individuals within a state equally rather than seeking to guarantee it for some limited class of individuals, and on this basis it stakes its claim to renewed attention. ${ }^{1}$

Part of the reason for the new republicanism's appeal is the promise of relief from the now rather shopworn debates over "negative" and "positive" freedom (see esp. Berlin 1958/2002; MacCallum 1967). Negative freedom-freedom from interference, coercion, and so on-has come to seem too dull, too philistine, or possessed of too limited applicability; positive freedom, on the other hand, perhaps spelled out as self-mastery or the achievement of the human essence in community with others, has come to seem too fraught with metaphysical or totalitarian baggage. Within this context, the virtues of republicanism stand out. The republican conception of freedom, as characterized by Pettit, possesses an estimable ancestry within political theory, a rich historical connection to the British and American Revolutions of 1688 and 1776, respectively, and an intriguing revisionary account of the history of freedom (Pettit 1997; Skinner 2006). This has opened new lines of argument and made it possible to look at old arguments, ideas, and authors in new ways. Most importantly, it has given us new questions to ask.

As the new republicanism's primary philosophical architect, Philip Pettit's main statements of the position-Republicanism: A Theory of Freedom and Government (1997) and On the People's Terms (2012)—will here stand as representative of the view. Ex ante, one imagines that the bold reconceptualization of a central political ideal would provide a robust and original political vision whose roots in the past prevent it from being entirely "radical" but that

1. For example, see Pettit $(1997,6)$ : "When traditional commonwealthmen and republicans hailed the ideal of freedom as non-domination, they only ever imagined that it was an ideal for an elite of propertied, mainstream males. ... But there is every reason why we should reappropriate their ideal and reintroduce it as a universal ideal for the members of a contemporary society." 
nonetheless poses significant challenges for the politics of today; we assume that bringing new questions to the fore and upsetting one of the age's shared assumptions should yield a politics to some significant degree independent of our common ways of thinking about politics. ${ }^{2}$ Yet the new republicanism, surprisingly, does not give birth to anything new; instead, Pettit reassures us that, although it may suggest reforms to our political institutions and practices, the republican conception of freedom will not shake existing left-liberal convictions. ${ }^{3}$ What republicanism offers is not novelty but a "rival axiomization of many [left-liberal] institutions" (Pettit 1997, 12) and a resulting greater conceptual simplicity and unity.

The new movement is often termed "neo-Roman" by its proponents, to emphasize that it is more concerned with non-domination than with democratic participation, in contrast to "neo-Athenian" theorists such as Hannah Arendt. Democratic participation is treated as an instrumental good to non-domination instead, and this, it is argued, is also what set apart Rome from Athens. But unlike Rome, the new republicanism maintains a self-conscious commitment to equality conjoined with the commitment to republican liberty; a republican constitution should contain no distinction between liber and servus. Is this move so powerful that it changes republicanism into something not too different from modern liberalism as represented by Berlin, which combines a commitment to negative freedom with a commitment to equality? ${ }^{4}$

To explore this question, we need two things: a standard of some kind for what republicanism is, and, if possible, a rival derivation of republicanism-cumequality to help us see what might be missing from or surreptitiously added to the new account.

For the first, Pettit points the way to a standard; he places great importance on the republican picture of the free citizen, an independent citizen who proudly looks others in the eye, who flatters and kowtows to no one, and who respects the rights of others while displaying servility to none. In Pettit's thought this ideal is given its fullest development in On the People's Terms through its incorporation into "the eyeball test": people "should be able to look one another

2. Pettit comes close to claiming as much in Pettit (1997, 11-12): "But though republicanism is organized around a modest and traditional starting-point, it is extremely fruitful and challenging in the theorems about government institutions which it allows us to derive"; however, he limits this challenge to institutions (not convictions). But cf. Pettit $(2012,19)$.

3. For example, "Left-of-centre liberals will find the republican line advanced in this book attractive, ... even the broad-brush strokes offered by way of sketching possible institutional designs should make it absolutely clear that the agenda supported by the republican argument is reformist and progressive in its implications" (Pettit 1997, 10).

4. Berlin stresses the need to balance a plurality of different values with one another, including freedom, equality, justice, happiness, security, and public order; see Berlin (1958/ 2002). 
in the eye without reason for fear or deference" $(2012,91)$. This test allows him a practical method of discerning whether a relationship or institution is marked by domination, contrary to the ideal. Regardless of this specific application, however, a certain picture of the independent citizen is central to both the new and the old republicanism, and as an ideal it gives republicanism a particular kind of spirit and source of appeal-namely, our conviction that this ideal portrays an attractive and important picture of citizenship and of what it means to belong to a particular kind of social and political order. Call this the appeal to the ideal of the free citizen. ${ }^{5}$

For the second part, a rival derivation of republicanism-cum-equality: if contemporary republicanism is about combining republican liberty with equality, then it is at least as old as Alexis de Tocqueville's Democracy in America. At many points, Tocqueville clearly conceives of himself as working within the republican tradition, and, moreover, he explicitly announces his goal to seek to understand how freedom can be secured under conditions of equality (see Tocqueville 1840/2000, author's introduction).

Oddly, Pettit provides only glancing mention of his work (see Pettit 1997, 19). This is significant since Tocqueville's politics and statecraft, unlike Pettit's, satisfy the ex ante requirement: they have proven variously attractive and challenging to both left and right, appealing to thinkers as diverse as Peter Lawler and Sheldon Wolin (see esp. Lawler 1993b; Wolin 2003). Tocqueville's conception of freedom and his analysis of the difficulties of establishing it under conditions of equality provide a conceptual framework for politics that is orthogonal to traditional or contemporary American and French political categories, one rich in challenging implications and surprising potential alliances. It will therefore provide our rival derivation of republican freedom as conjoined with equality.

With our standard and our comparison now in hand, we can focus on our main problem, restated as follows: Does the new republicanism leave something important out of its derivation and conceptualization of republicanism-something we can see is missing from the way it develops the ideal of the free citizen? Also, is there something else being added to the picture beyond the admittedly new commitment to equality? Last, we might also ask, could a republicanism that paid adequate attention to the work of Tocqueville provide a more challenging and yet also more satisfying conception of republican politics?

5. Pettit uses "the image of the liber or "free person'" as "a guiding heuristic" for his theory $(2012,82)$. Pettit lists the appeal of being able to "look others in the eyes" as among the primary personal attractions freedom as non-domination holds for him (1997, viii). Good examples of Pettit's use of the appeal can be found at Pettit $(1997,5,60,268)$ and Pettit (2012, 2-3, 17, and esp. 82-88, where the eyeball test and "free person heuristic" are formally introduced). 


\section{THE FORGOTTEN FOREBEAR}

Tocqueville accepted the new republicans' central insight, that freedom requires freedom from domination and dependence, and he shared their concerns about the danger of arbitrary power and its tendency to degrade the souls of those subject to it. Like Pettit, he gives great importance to a certain kind of pride and spirit of resistance among the citizenry; he too feels the appeal of the ideal of the free citizen, and although he does not provide a single treatment of democratic spirit that would draw together his scattered observations and treatments of the subject, Tocqueville's thought is marked by a concern with instilling such spirit in citizens (see Tocqueville 1856/1998, 171; cf. Pettit 2012, 3). But Tocqueville never concludes that the mere absence of domination could create such citizens, or that freedom could be reduced to such, and he is concerned about how such a spirit of independence might operate in the absence of a democratic political institution (see esp. Tocqueville $1856 / 1998$, bk. 2 , chap. 11 ; bk. 3, chaps. $1-3$, 8). Why is this?

Republicanism's ideal of the free citizen is an "ideal type," ${ }^{6}$ in Weber's phrase, and is usually introduced through what we might term an "ideal distinction" between slave and free, whose function is to simplify the features of social and political phenomena so as to focus attention on certain important aspects of these phenomena, with the purpose of eliciting specific moral responses and intuitions. So too Tocqueville's understanding can best be introduced through examining his conception of aristocratic freedom and the "ideal distinction" between the aristocrat and the peasant. According to Tocqueville, social state determines how someone experiences his ability to act in the world, and this "internal state of the soul is reproduced in mores" (1840/2000, 24). Thus, the aristocratic type is powerful and free, with a lofty soul and lofty manners, while the peasant experiences constant reminders of his inferiority and dependence, which renders him to varying degrees both insolent and base (I treat this more fully in Jech 2013). The reason he invokes this distinction is to introduce and buttress yet another distinction, between the two aristocratic types and the singular democratic type. This is due to his understanding that altered social conditions create a great historical chasm between ourselves, who live in a democratic age of equality, and previous generations, who lived in ages of aristocratic inequality. This gap is fundamental to how he understands the task of securing freedom, for he thinks that different social structures necessitate different means.

6. The use of "ideal types" in social theory precedes the work of Max Weber, but it is Weber who is most responsible for clearly articulating their purpose and making self-conscious use of them to clarify practices such as capitalism and bureaucracy (see Weber 1905/2010; 1946, 196-244). 
According to Tocqueville, aristocratic societies are extremely unjust but remarkably secure from despotism. There are three main reasons he identifies for this: aristocratic societies possess a plurality of great lords with power independent of the king or sovereign; aristocratic societies combine individuals into classes that have common interests and that facilitate common action; and in the midst of hierarchy, aristocratic societies also have room for the free combination of those who are neither lords nor bound vassals or serfs, which has typically appeared in the towns, aiming to rival the power of the great lords. He emphasizes the first of these in Democracy in America, arguing that so long as a society possesses great lords, no single individual can completely dominate society or do what he likes without opposition: "Aristocratic societies always contain within them, in the midst of a great multitude of individuals who can do nothing by themselves, a few very powerful and very wealthy citizens; each of these can execute great undertakings by himself. In aristocratic societies men have no need to unite because they are kept very much together" (Tocqueville 1840/2000, 480).

The action of common classes tends to receive only minor attention (Tocqueville 1856/1998, 171-79). The later Tocqueville, author of The Old Regime and the Revolution, is most interested in the models of freedom and mutual aid present in the medieval towns and parishes, which are the most fragile, but also the most appropriate for us today (see Tocqueville 1856/1998, bk. 2, chaps. 9 and 10).

Since the most essential feature of aristocratic societies is the first of these, their organization into a plurality of structures of dependence and command, their primary means of preserving freedom is to preserve the freedom of some at the expense of the many. English freedom, insofar as it flows from the Magna Carta and the feudal barons' opposition to the power of King John, arose from precisely this dynamic of aristocratic societies. ${ }^{7}$ But the concrete basis of aristocratic freedom is injustice. In aristocratic societies each great lord is set atop a great involuntary association of individuals whose assistance he can immediately call upon to engage in whatever undertakings he chooses to pursue, a right supported by coercive force.

Even societies located at the egalitarian limit of aristocratic social state, such as Rome or Athens, provide equality only for citizens, not for the more numerous noncitizens. This social order gives rise to and is sustained by the aristocratic "dogma" that the basis for the division of ranks lies in human nature itself, in the division of humanity into some who are naturally superior and others who are naturally inferior (Tocqueville 1840/2000, 412-13). The

7. Tocqueville notes similar episodes, "which seem to belong to English history," during the earlier stages of the French Old Regime before the triumphs of absolutism and centralization (1856/1998, bk. 2, chap. 9, and 155). 
freedom of aristocratic societies, then, depends on persistent injustice and a false conception of human nature. In such societies there is always a small but considerable body of individuals with the capacity to independently initiate action and who cannot be easily cowed or oppressed. But in such a society inequality does not just coexist with freedom; it is actually the means of securing it.

Therefore, from Tocqueville's perspective, Pettit has not begun to grapple with the radical challenge in moving from an aristocratic freedom, where some are made independent through the subjection of others, to democratic freedom, where all are to be made equally free and independent. He recognizes that it will be difficult to achieve this goal, but he does not seem to recognize, as Tocqueville does, that the task and challenge of democratic statecraft is not to go further than before but to make use of entirely different means for securing freedom. Seeking equality without providing new conditions for the exercise of freedom can be disastrous because, as Mirabeau wrote to Louis XVI, on its own "equality facilitates the exercise of power" (Tocqueville 1856/1998, 97-98; Bronowski and Mazlish 1960, 400). The efforts of those pursuing equality as an end may be exploited by those seeking to appropriate it as a means to other ends. For this reason, when the French Revolution had finished its great works of destruction, it left behind not a free people but "an immense central power" without rivals within the state, easily appropriated by forces hostile to freedom (Tocqueville 1856/1998, 98; Markell 2008, 31).

It is in view of considerations such as these that Tocqueville says, "In democratic centuries like ours, association in all things must gradually replace the dominant action of a few powerful individuals" (2002, 150; cf. Tocqueville $1840 / 2000,9)$. This provides the great aim of democratic statecraft-providing the new conditions suitable to equality that will make freedom possible through what Tocqueville calls "the art of being free," that is, an art of free association to replace the old practice of forcible association beneath a great lord. Such associations may do all the things that a great lord might do in an aristocratic society, all the great and small things that go beyond the power of an individual to accomplish alone.

Because of historical circumstances rooted in their colonial experience, Americans tend to take this art for granted, but providing the conditions for it to be best used is a remarkably difficult task; Tocqueville, used to what had become French customs in this regard, was astonished at the range of objects Americans used the art of free association to achieve: "to give fêtes, to found seminaries, to build inns, to raise churches, to distribute books, to send missionaries to the antipodes; [to] create hospitals, prisons, [and] schools," and even, as in the case of temperance societies, to provide a moral example (1840/2000, 489, 492). 
In terms of concrete policy and statecraft, providing the conditions of free association requires a wide-ranging policy in favor of the means by which individuals associate with one another, consisting in providing the conditions for popular involvement in government, in encouraging such involvement, and in promoting civic association within society itself in similar ways. Statecraft and policy based on Tocqueville's vision go beyond the negative role of the state envisioned by those who favor negative freedom above all, but this specific positive role is at odds with the role given to the state by contemporary republicans like Pettit. ${ }^{8}$ A Tocquevillian platform could be generally antibureaucratic, ambivalent about markets, generally favorable to labor unions (although perhaps not all kinds or all methods of organization), widely favorable to local democratic organization, and so on. ${ }^{9}$

So Tocqueville's derivation of republicanism differs from Pettit's by positing an important distinction between the social conditions of the old republicanism and our own social conditions-the very social conditions in virtue of which equality has become a viable and important ideal—and discerning a corresponding change in how we should establish laws, institutions, and customs, especially with respect to establishing freedom. We ought naturally to ask why this should be. Why should this change in the social landscape-in social state, as Tocqueville puts it (best conceptualized in Zuckert 1993)be so important for freedom? Why should freedom be sensitive to social state? Is this sensitivity to social state relevant to the ideal of the free citizen, or does it come from somewhere else?

To address this, we shall have to do a little philosophical work concerning the nature of combined action and its relationship to freedom. When we are done with this, we shall be able to come back to the ideal of the free citizen and ask how, and whether, Tocqueville's thought represents a more faithful derivation and conceptualization of republicanism-cum-equality.

\section{RESPONSIBILITY FOR COMBINED ACTION}

This philosophical foray will proceed in two stages. The first of these, discussed in this section, concerns the nature of combined action. The second, treated in section 4 , concerns the ideal of freedom associated with such action.

8. An examination of Tocqueville's speech before the constituent assembly in 1848 gives an indication of how different his policy might be from either "left" or "right" today; see Tocqueville (1991, 196; abridged English translation in Tocqueville 2002, 250-51).

9. It may also be unsuitably imperial, if Tocqueville's Algerian writings are any guide; I'll leave that aside, as it is not clear that this aspect is related to the core of Tocqueville's political thought in an important way. 
Pettit defines domination as the capacity to interfere on an arbitrary or uncontrolled basis in certain choices that someone is in a position to make (1997, 51-79, esp. 52; 2012, 26-74, esp. 26 and 58). Note, however, the word "choices"-it gives a particular direction to his whole political theory, and to a greater degree than one might first suspect. Consider what kinds of things come under the heading of choice, of the things that a person might chose to do: someone chooses a religion, chooses to speak, chooses which clothes to wear today, chooses to open an umbrella, chooses which route to take to work, chooses to spend money on one product or service or another, and so on. When it comes to one's private life and one's private interest, choice has its place, for it is within this domain that what one chooses and what one does are most reliably one and the same.

But the word "choice" is deceptive, even in the realm of intimate private life, because so much action is not singular but combined. We propose or join a combined action, but we do not choose it. Someone may choose to make or accept a marriage proposal, but no one can choose to get married to someone, or even to become friends with someone. And beyond private life, one finds such actions on all sides, as Tocqueville's list of Americans' combined actions makes clear-ranging from starting a chess club to testing a theory in particle physics to making revolution.

Consider then some great and large nation or people. Among this people there is activity of all kinds going on; many of the most important goods in human life are achieved only through combined action, and in any people with an ongoing and growing civilization human energies and activity in pursuit of attaining and securing these goods will be continuously ongoing. We will see this going on in agriculture, marriage, trade, construction, art, religion, science, philosophy, athletics, and all kinds of human enterprise. Some of this activity involves goods that can be achieved by individuals acting alone or in groups of two or three intimates or acquaintances, but much of it requires the kind of combined activity that requires individuals to act together in groups larger or less intimate than that. Let this category of actions taken by individuals in combination with others be termed combined action.

Within combined action there are several different ways that activity might be organized, for which I introduce the following terminological distinctions:

1. Joint action: action begun and carried out through the free initiation and free combination of individuals.

2. Collective action: action begun and carried out through the initiation of some individual in the community utilizing local forms of selfgovernment after persuading other citizens to agree to pursue the proposed goal. 
3. Legislative or executive action: action begun and carried out through the initiation of some elected and accountable individual with the ability to direct state power.

4. Administrative action: action begun and carried out through regular bureaucratic administration.

This set of distinctions is not exhaustive-it lacks, for example, a way of categorizing many of the various modes of combined action made possible under aristocratic social state-and it may or may not resemble the way that Tocqueville would have classified such actions. It should, however, serve present purposes.

Let us examine a case of combined action that illustrates the features of these different ways of pursuing action, beginning with the fourth category, administrative action.

A school is built. Someone attends the school and later in life attains success. She is grateful not only to the particular teachers who taught her but also to whomever it was who thought to establish a school in her neighborhood. The matter is harder to discover than she initially supposed. The school was established in accordance with a certain rule, as determined by a particular government office; within the office itself, the matter was not so much decided as approved by a particular worker, and then by the worker's supervisorthough "approve" is too strong a word, since all the worker did was examine certain demographic data, discern that a certain rule applied, and then file a particular form, which initiated the whole process, and the worker's supervisor did no more than stamp the form as it crossed his desk, in accordance with ordinary operating procedure. Land was bought, a building was constructed, administrators and teachers were hired, but the grateful woman found no particular individual whom she might thank. She could not go to the foreman of the construction crew, say, and thank him for building the school. He only did what he was paid to do; it wasn't his idea-he may have even thought it was a bad idea to build the school, but what business was it of his? Likewise, the bureaucrat with whom the process began did not necessarily have any intention of building the school; he may have barely spared a thought for the suitability of the rule in accordance to which new schools are scheduled to be built, and may only have carried out the function of his office, whose duties are precisely defined and spelled out, telling him to "file such-and-such a form whenever suchand-such conditions are met." In such a case, a new school has been built, but it may not be accurate to say that anyone has built it. The most one might say is that she could be grateful toward whoever drafted the original law or rule, though even this might be difficult to pin down. Combined action as administrative action becomes the social analog of the unconscious processes of bodily 
life, and as the different components of the body act together to maintain homeostasis, a telos without a corresponding active intention, so the activity of society is pursued without anyone willing it to be so. Such are matters when the administration of things replaces the government of men.

Perhaps, though, the case is different, falling under category 3, legislative or executive action. Perhaps what the woman finds is that the school was built through the initiative of a certain elected officeholder, who was mayor at the time and, discerning the need for a new school in the area, championed building a school there and saw the matter through to completion; or one of her state's senators included it as a little quid pro quo in exchange for voting on a certain bill that was made into law; or something else of the kind happened.

Or perhaps the school was built because some individual living in the community saw the need, in which case it would fall under category 2, collective action. He thought that the area could use its own school and shared his idea with others, gathering support in the community by proposing the idea and gathering their support; finally, the community, through its governing body, established the school. In either of the last two cases she knows whom to thank and whom to attribute responsibility to for establishing the school. In category 3 she has the particular officeholder to thank, and in category 2 she can thank both the one who proposed the idea and those who joined with him to accomplish it.

But perhaps it was none of these; perhaps instead some individual in the community, who knew a thing or two about education, was unhappy with what she found and disapproved of the kind of education her child was getting in the existing schools. She disagreed with their educational philosophy or disliked the crowded conditions and lack of individual attention students received in the existing schools and decided to found a school of her own, following her own educational philosophy. She proposed this idea to others, gained their support, and through this support acquired the funds, the building, and the other resources necessary to build the school. Then she opened the school, the one that this later woman attended and is so thankful for. This was action under category 1 , joint action. Here, as in category 2, we can establish a twofold responsibility-the greater responsibility goes to the woman whose idea and initiative began the process, but responsibility (of another kind) also goes to those who joined with her in supporting her initiative and helping her accomplish it.

In considering the different possibilities for how joint action is achieved, a certain fact becomes apparent. The higher up the list we move, toward category 1 , the more individuals are involved in freely determining the direction of activity in these aspects of human life. To the extent that combined actions 
in some sphere of human life are categorized near the beginning of the list, members of society retain responsibility for freely conceiving, initiating, and joining in the pursuit of combined activities in this sphere of life. This is particularly apparent in categories 1 and 2, joint and collective action, respectively. In those categories action is divided between the act of initiation (which takes the form of a proposal rather than a command) and the act of joining or choosing to participate in the action taken by those who voluntarily join or contribute to or otherwise support the proposed combined action.

In joint action, matters are entirely left up to the members of society, acting freely, to pursue the relevant goods in these areas of human life; no one else performs or organizes these tasks for them, though they may establish or regulate the conditions of pursuit. As we move down the list, fewer members of society are given responsibility for action. To the extent, then, that society leaves more individual members with the task of conceiving, initiating, and joining in combined action in this way, the members of society can also be considered to be responsible for those aspects of human life. To the extent that we move in the other direction, they are given less and less responsibility, as these affairs are brought under the authority of some specially appointed group within society.

The reason social state makes a difference is that under aristocratic social state some individuals always possessed such responsibility, whereas in democratic social state it is not clearly the case that any individuals at all need to possess responsibility for combined action. This does not say anything about whether any particular sort of activity ought to be handled through joint action or administrative action or anywhere in between. Perhaps, indeed, it is right that the more of society that is governed by regular bureaucratic processes, the better; some very able thinkers have thought so. Tocqueville, however, did not. Why not? Why does it matter if the citizenry is more or less responsible with respect to important aspects of human life? In particular, how is such responsibility related to the ideal of the free citizen?

This takes us to the second stage of the argument. Let us see whether this foray into the philosophical thickets can bring us home to the free citizen.

\section{A FREE PEOPLE}

Let us introduce a second ideal, the ideal of a free people. For now, we'll treat it as a provisional ideal; dialectically, we are concerned with this new ideal only if it can be properly traced back to the ideal of the free citizen. A "free people" as we're here defining the term is a people whose members are responsible for the most important matters concerning them. In Patchen Markell's terms, they 
are not only free from dominating control but also free from usurpation of involvement in public activity (see Markell 2008). As an ideal it may be approximated to various degrees by different peoples at different times according to the different circumstances that they face. It is quite rare for many members of a society to be responsible for freely conceiving, freely initiating, and freely joining activity within these spheres.

Members of a free people, however, not only act freely with regard to their most private and individual interests but also freely join together for the sake of securing common goals and interests or achieving objects that lie beyond the power of an individual to achieve without combined action.

If we accept this ideal of a free people, then, it will matter very much to us to what degree most members of society are left with the responsibility for combined action in the various important spheres of human life. We will be sensitive to both domination and usurpation, and we will wish to secure the conditions under which as many members of society are capable of engaging in combined activity as possible and pursuing the tasks of republican statecraft in a form similar to that conceived of by Tocqueville. The natural question to ask is, why should we accept the form of freedom embodied in this ideal?

Markell's argument against Pettit's republicanism, as just mentioned, focuses on the difference between domination and usurpation as two different ways of limiting agency. The problem with slavery is not only the presence of domination. Markell argues that the injustice of slavery operates along "multiple dimensions" $(2008,27)$. If there is an injustice in making the slave subject to the master's will, to become the "instrument" of the master's will and the performer of his labor, then there is a second injustice in restricting the slave to involvement in a limited set of activities. In the example of empire, such injustice appears especially sharply when a benevolent imperial power is devoted to a mission of human rights, so that although its policies and governors may track subjects' interests, its rule still appears unjust.

Markell's argument draws attention to the possibility that Pettit's conception of freedom is rooted in a mistake about what is involved in agency, but the injustice mentioned is not clearly described. The danger of this mistake about agency is cashed out in terms of the danger of misunderstanding the agency of the state; Pettit envisions the state as a kind of servant or slave of the citizens, and Markell warns, "This view misdescribes the relation of the state to its citizens in much the same way that slaveholders' ideology misdescribed the relation of slaves to masters... [The] scandal of the state [under this view] is that it, too, always turns out to be more than the obediently robotic servant of its citizens" $(2008,31)$. Having entrusted all political action to the state, the citizens are liable to become aware, as slaveholders are liable to become aware, that they are vulnerable to the servant precisely because it has sole command 
of certain spheres of action. As Marx later said in a related context, speaking of the short-lived French parliamentary republic of 1848-51, of which Tocqueville himself was an anxious member, "It required only a thrust of the bayonet for the membrane to burst and the monster to leap forth before our eyes" (1996, 112).

This argument provides a reason why a citizen may wish to retain involvement in political affairs out of fear of later tyrannical misuse of usurped power, but not why this involvement is itself important. In particular, it still seems unclear whether democratic involvement is part of the ideal of the free citizen.

To answer this question, let's adapt one of Tocqueville's most well-known arguments. The young Tocqueville, perhaps remembering Napoleon, still feared the tyranny of a caesar (Tocqueville 1840/2000, 301; cf. 621); visiting America, Tocqueville came to fear the tyranny of an unrestrained majority (vol. 1, bk. 2, chaps. 8 and 9); but reflection and experience brought Tocqueville finally to fear a different kind of despotism. The object of Tocqueville's mature fear was a state that subjected its citizens to perpetual tutelage, for their own benefit, and thereby gave them few opportunities for the significant use of freedom (vol. 2, bk. 4, chaps. 6 and 7; cf. Tocqueville 1856/1998, 131). Having so few opportunities for engaging in combined action and becoming "pusillanimous and soft" (Tocqueville 1840/2000, 672), "they will soon become incapable of exercising the great, unique privilege that remains to them," that of choosing representatives, and "one will not make anyone believe that a liberal, energetic, and wise government can ever issue from the suffrage of a people of servants" (665). Thus, Tocqueville concludes that democratic statecraft must take care to attend to democratic character and that the primary means for this is through the experience of freedom in combined action.

In explaining this final despotism he appealed not to the ideal distinction between slave and free or between aristocrat and peasant but to that between adults and children (Tocqueville 1840/2000, 663). Children too are unfree, not by slavery but by tutelage or guardianship. Even when parents exercise authority only in a way that tracks children's interests and without domination, children are not significantly free. The most important things in their lives are not up to them, either to decide on or to pursue; ${ }^{10}$ small children are free only with respect to the least important matters, such as choice of their amusements, while older children acquire greater independence, but only regarding private matters such as friends and directions of study, and not always even regarding the most important of these. Because children lack responsibility and are not trusted with matters of importance, the transition from childhood to adulthood is a significant transition toward freedom and the government of 
one's own life. The relationship between adults and children, then, also establishes an ideal distinction regarding freedom, and the more that some person or group resembles one pole of the distinction, the more we can regard someone as either free, on the one hand, or unfree, on the other.

The distinction between these two groups consists primarily in the independence of judgment and action they are entrusted with regarding matters of importance, regardless of whether the control exercised is "dominating" or not in Pettit's sense. Thus, we must also say that the ability to judge matters of importance and pursue important goods oneself, rather than being subject to the judgment of another and receiving goods from another, is itself a mark of freedom. It is from this that we can derive the conclusion that a free people will be one whose members are entrusted with matters of importance, including those requiring combined action.

Should we agree? Let's review what has been said. What divides combined actions falling into the top two categories (joint action and collective action) from those falling into the lower two (executive or legislative action and administrative action) is the degree to which matters of importance can be left to the people to secure for themselves and to what degree they cannot be trusted to do so. When these conditions obtain, "public business" is the business of the members of society, the citizens, themselves. In particular, the citizens are involved in significant kinds of action and decision-making, where important matters are at stake. "Involvement," so understood, is important principally because of the importance of the types of activity that are being usurped. This connection to the importance of the types of activity from which citizens are being excluded brings us back to the ideal of a free citizen, as someone with grounds for pride and a spirit of independence. Surely involvement in important affairs is a ground for such pride and spirit, and so in accord with the ideal of the free citizen.

But let's not be too hasty. Whether the people are to be trusted with such responsibility seems an empirical question, whose answer varies with conditions. Moreover, let us imagine the following challenge: You've proffered this theory of combined action and the new distinction between adults and children as grounds for supporting a republican theory of liberty that combines non-domination with involvement in public affairs. But we need to be more careful here: haven't we been awfully free with the ideal of the free citizen? It is one thing to go on talking loosely about pride, independence, and so on; it is another to properly conceptualize something into a coherent, differentiated, and developed idea. Before we can say whether both derivations properly belong to the ideal or not, we ought to make sure we understand the ideal and specify in what ways these rival conceptualizations derive from it. Then we will know better whether we are justified in speaking of a free people, as 
defined above, as a social and political ideal, and of the capacity to freely conceive, initiate, and join in combined action as a form of liberty.

\section{THE IDEAL OF THE FREE CITIZEN}

At the start of the Revolution ... the French were proud enough of their cause and of themselves to believe that they could be equal in freedom. (Tocqueville 1856/1998, 244)

Having returned from our philosophical foray, we can now ask which derivation of republicanism best accords with the ideal of the free citizen-one embodying Pettit's philosophy of non-domination, or one based on Tocqueville's vision of freedom in combined action?

Central to Pettit's argument for republicanism is the vivid case he makes for the value of a liber or free person being able to "look others in the eye," a thought expressed in a variety of different forms in his arguments for republican freedom and embodied in his "eyeball test," consisting in the ability to look others in the eye without reason for fear or deference. Pettit's descriptions of the power of domination to require those subject to it to "bow or scrape, toady or kowtow, fawn or flatter" for the sake of pleasing a dominating party strike the reader as clearly undesirable $(2012,82)$; or, in Skinner's words, we object to the way that "servitude breeds servility" $(2008,213)$.

The importance Pettit assigns to being able to look others in the eye illustrates how the spirit of independence invoked by the appeal to the free citizen is essentially a kind of reflective self-understanding, the citizen's conception of himself qua citizen, based on how he is related to others in terms of his social and political condition. The ideal of the free citizen so understood, then, is principally an ideal of living in freedom from a kind of degrading relationship that would cause us to have a different kind of self-conception and create a different kind of spirit and character. The citizens' endorsement of this selfconception both for themselves and for their fellow citizens is what animates Pettit's republic: "[Republican] institutions cannot walk on their own. They are dead, mechanical devices, and will gain life and momentum only if they win a place in the habits of people's hearts" (Pettit 1997, 241). They must possess them as a kind of "civic virtue" or "civility," as Pettit prefers to put it. Civic virtue in Pettit's republic will consist primarily in internalizing the norms of non-domination and in identification with fellow citizens, especially vulnerable groups among them (245).

Turning to Tocqueville's conception of republicanism and the free citizen, we raise the following natural questions: Why think that "involvement" matters? Why care whether a society makes participation in combined action available or not? Tocqueville sometimes treats the good of freedom as a kind 
of unanalyzable first principle, saying that the love of liberty has no basis but a "sublime" feeling, and that this feeling cannot be explained to any who lack it $(1856 / 1998,217)$. This, however, is Tocqueville's view of all first principles, about which he tends toward a Pascalian pessimism. ${ }^{11}$ To properly appreciate the good of liberty in Tocqueville's thought, we need to secure a wider context, which can allow us to understand the value of political liberty and the capacity to participate in combined action.

The starting point for his argument for the citizen is implicit in the ideal distinction between adults and children. Although a child may have things to be proud of, it would be absurd for an adult to regard the same things as grounds of pride; the kind of activities that a child engages in, compared to those engaged in by an adult, distinguishes the two. We have seen that a citizen belonging to "a free people" will have the capacity to propose, initiate, and join in combined activity. This means possessing, and understanding oneself to possess, the capacity to engage in a particular class of activities distinct from that of combined actions but overlapping with it and related to it in important ways, a class I here term free actions.

Free actions specify a range of actions with several qualities, in virtue of which these actions can be classed in terms of degree. The maximum case of free action (what I elsewhere call greatness-in-action; Jech 2016, 121-30) provides a good way into the larger class, by drawing free actions' features in the most vivid colors. Examples of greatness-in-action include an aristocrat's extravagant vices (Tocqueville 1840/2000, 936); the making of magnificent tombs (43); Renaissance painting (795); the American Pilgrims' founding of a new colony where they would be free to worship (54); the actions of the American statesman George Washington in the founding and in establishing the direction of American foreign policy, a greatness most completely expressed in his resistance to the exaggerations of popular passion $(190,371)$; and the actions of the revolutionary generation during the first stage of the French Revolution (Tocqueville 1856/1998, 244).

Actions included in this class possess three interrelated properties: (1) they are free, that is, the action is not motivated by material necessity, or at least not directly necessitated by instinct or by material needs; (2) they possess ideality, namely, the action originates "in the soul," that is, in an idea or ideal, an intellectual, moral, or spiritual need; and (3) they require mastery, that is, the action requires effort, skill, or power to realize the idea in the world. There isn't space here to analyze these actions thoroughly, but a few remarks are necessary.

11. See Tocqueville $(1985,63)$ for a summary of Tocqueville's view and Jech (2016) for an extended treatment of this aspect of Tocqueville's thought, including a delineation of his points of disagreement with Pascal. 
The freedom required for greatness-in-action includes not only non-domination ("the pleasure of being able to speak, act, and breathe without constraint, under the government of God and the laws alone"; Tocqueville 1856/1998, 217) but also freedom from material need or natural necessity. The construction of tombs, the production of fine art, and the pursuit of "liberty, equality, and fraternity" do not fill the stomach or clothe the body.

The ideality marking these actions connotes something beyond the ordinary and the everyday: modern painters are exact anatomists, but Renaissance painters "looked above themselves" for "great subjects"; Raphael "sought something better than nature" and "gave us a glimpse of divinity in his works" (Tocqueville 1840/2000, 795). Yet ideality is more wide ranging than simply goodness, beauty, and truth, as evidenced, for example, in the fact that Tocqueville thought that vices could be great and that the Pilgrims' goal was great without being true. Tocqueville has an expansive and liberal conception of ideality instead, requiring only that an action pursue an idea or ideal grounded in thought. ${ }^{12}$

Finally, none of these actions could be executed without overcoming difficulties through a combination of skill and knowledge of the subject of action, that is, without displaying a mastery of the material environment that allows the actor or actors to bridge the gap between the realm of thought, where the idea or ideal arose, and the realm of the body, where this idea is now to be realized and achieved.

Some actions manifest these qualities to a very high degree, such as those mentioned above. But since the degree to which an action can manifest any of these three qualities varies, the class of free actions occupies a much larger space, space that includes actions like founding a school. It is also significant that although some free actions are capable of being carried out by a single individual acting alone, as in the case of a great artist like Raphael, many free actions, and perhaps most of them, are also cases of combined action and must be carried out by many people acting together. Thus, an important aspect of the freedom to engage in combined action is the freedom to initiate or join in those free actions that are impossible for someone to perform acting alone.

What is essential to Tocqueville's conceptualization of republicanism is the connection he sees between free, combined actions and free citizens. This connection can be traced as follows. Some kinds of free action can be performed by individuals acting alone, but many, and perhaps most, cannot: their perfor-

12. For further development of this theme of ideality, see Jech (2016), but see also, for differing views of the same, Lawler (1993a, 1993b) and Kahan (2015); Kahan draws this domain in terms of our need for "spiritual balance" (something he has also explored in unpublished work on Tocqueville's conception of human nature, where he compares "material" with "non-material desires"), and Lawler in terms of mental "restlessness." 
mance requires combined action of some kind. Crucially, Tocqueville thinks that there is something especially essential about collective action, that is, free political action, in making the other forms possible or, rather, known and recognized as possible. It is only when these conditions are met that citizens come to regard themselves as being responsible for such actions. This sense of responsibility shapes their reflective conception of themselves as citizens; it teaches them that they are the type of beings who engage in free actions, actions that manifest freedom, thought, and skill.

Finally, because the difference between free actions simply and greatnessin-action is one of degree, citizens can understand their relation to those who perform these actions as also being one of degree, not of kind; they know that they are not essentially cut off from such greatness. Since it is through learning to handle less important matters that we become ready for the more important ones, one cannot entrust the unimportant matters to administrative action and leave just the most important of all to the people: "Subjection in small affairs manifests itself every day and makes itself felt without distinction by all citizens. It does not make them desperate; but it constantly thwarts them and brings them to renounce the use of their wills. Thus little by little, it extinguishes their spirits and enervates their souls. ... In vain will you charge these same citizens, whom you have rendered so dependent on the central power, with choosing the representatives of this power from time to time" (Tocqueville 1840/2000, 665).

From Tocqueville's perspective, such a system of government is a great system of civic dis-education. The free citizen's spirit and pride of citizenship consist in identifying himself as the kind of being who can, in principle, engage in free actions, on the basis of actual experience and practical knowledge of such.

This explains Tocqueville's bitter opposition to centralized bureaucratic states, where the most important affairs do not belong to anyone in particular; these societies show "insufficient confidence in the independence and judgment of ordinary people" (Mahoney 1993, 188), and as a result, citizens' self-reflection cannot incorporate responsibility for such affairs. Aristocratic pride consists in placing responsibility for combined action within a few particular families, which incorporate its power of achievement into their self-concept; members of aristocratic societies know that at least some people possess the requisite qualities to take on such tasks. ${ }^{13}$ Such arrangements, by allowing the state to become "his master, his tutor, his schoolmaster ... for fear of letting a man fail" (Tocque-

13. Compare Manent $(1996,68)$ : "By placing certain men in a sublime social position, the aristocrats set forth a sublime idea of man, and stimulate in some men (who are not necessarily the same as the first) sublime efforts. ... Nothing of the kind takes place in democracies, where nature is left to itself, and where it therefore runs the risk of falling short of its potential." 
ville 1968, 183), throw individuals back on themselves and divorce them from a context in which they could participate in significant free actions, so that they "[fall] gradually below the level of humanity" (Tocqueville 1840/2000, 1259). Democratic pride requires diffusing this capacity to engage in combined action widely among all citizens, which requires widespread potential for individuals freely coming together in action.

So which version of republicanism best answers the appeal to the ideal of the free citizen? Pettit considers the free citizen in republican thought to be someone "who [lives] within his own domain ... on terms that he himself [sets]" (2012, 17). According to this vision, each member of society occupies a "domain" that we can characterize as the space within which that member exercises freedom and makes choices. Pettit primarily emphasizes the fact that within this domain the citizen acts without needing to rely on anyone's pleasure or approval (freedom from domination), and gives secondary emphasis to the "size" of this domain (the range of choices over which one enjoys such freedom; see Pettit 1997, 76; 2012, 26-27).

Regarding these features, Tocqueville's and Pettit's conceptions of the free citizen overlap. Tocqueville appeals to "the pleasure of being able to speak, act, and breathe without constraint, under the government of God and the laws alone" $(1856 / 1998,217)$. Thus, his free citizen too is marked by the possession of a domain in which he acts without needing anyone's pleasure or approval. Freedom to initiate and join in combined action is difficult to reconcile with domination.

There is a significant difference between how the two corresponding philosophies conceptualize the ideal of the free citizen, however. Pettit is sensitive to two features of the citizen's domain but omits a third, extremely relevant feature: the importance of the objects lying within the citizen's domain. It is not enough to expand the range of choices available to someone, if the most important matters remain up to someone else, even if these matters are decided on in a non-dominating fashion. But many of the most important objects are obtainable only through combined action, and this is precisely what freedom of initiation is designed to guarantee for the ideal free citizen - the freedom to conceive, initiate, and pursue objects lying beyond the power of a single individual to attain, rather than by a power such as the state. The value contained in the ideal of the free citizen is, for Tocqueville, based in the value of the citizens being suited to responsibility for important aspects of human life, and their democratic pride is based in their knowledge that they are fit for this responsibility and identifying these aspects and activities as in some sense "their own" (see Jech 2013). Such citizens, closed to their greatest possibilities, fall into the danger of becoming Nietzsche's "herd" or Kierkegaard's "the crowd": enforcers of uniformity and mediocrity. 
Pettit's theory as stated doesn't seem to leave any room for evaluating action in terms of anything that would suitably fill the same role, and his version of the citizen seems to lack an important range of grounds for pride that the citizen possesses in Tocqueville's derivation. This is all the more striking because in his other work, Pettit has provided ample theoretical resources for articulating what is at stake here in a way that would avoid many liberal worries over making republicanism dependent on an overly substantive view of the human good: these resources are in his theory of group agency. We cannot explore this theory here, but in outline, Pettit could treat freedom of combined action as a kind of freedom with respect to group agency, where what hangs in the balance is whether citizens possess the freedom to initiate the creation of, or to join, "group agents" (see List and Pettit 2011). Such group agents allow their members to pool resources in a rational and coordinated way in order to accomplish tasks that these members could not achieve individually. Had he taken this route, his republicanism might have provided an extremely valuable and precise articulation of what is involved in combined action. Since he did not do this, however, we must admit that the two derivations diverge in how they appeal to the ideal of the free citizen.

Now, we might raise the following objections: Are the activities that require freedom of combined actions really so important? Do they really provide such significant grounds for the pride of the citizen? To this, the Tocquevillian can make the following response: The neo-Roman republicans' attention to history ought to have taught the lesson the Persians were forced to learn from the 10,000 Greek mercenaries whose generals they had kidnapped, whose lower officers they had murdered, but whose ability to freely govern themselves they could not wipe out. Isolated in the heart of Persia, 10,000 Greeks elected new generals, and, despite all that was arrayed against them, 6,000 successfully marched out from the Persian Empire to return safely to Hellas. Their success is attributable not only to their ease with democratic procedures but also to their understanding of themselves, their sense of the kind of tasks that they could successfully take on. And isn't this, quite simply, the free citizen we are seekingthe free citizen whose spirit and pride in citizenship are matched by his sense of what he can accomplish with others?

Now, we should be careful. We shouldn't make too much of a single example, as if such marvels are automatically entailed by the habit of combined action, but it is profitable to consider the point. To the extent that it is right, Pettit's free citizen lacks important grounds for pride and democratic spirit that the Tocquevillian citizen possesses, for the latter understands that the kinds of important projects that require group agents are in principle open to him and those for which he might become responsible, and his self-conception will include the belief that he is, after all, the kind of person who might pursue these 
tasks. This is the reality that the ideal distinction between adults and children invokes. The adult has an intellectual maturity and level of skilled competence that is translated into responsibility for actions that require intelligence, foresight, and skill—a responsibility not given to children.

In light of this, we can imagine a further Tocquevillian argument. According to Pettit, the citizen's sense of self-worth is social in character and based on the fact that he need not show deference to anyone. He is an equal among peers and is therefore able to look his fellow citizens in the eye (Pettit 2012, 83). But we can imagine the following Tocquevillian rejoinder: to have pride in one's status as citizen is comical if one is restricted from responsibility for the most important matters, which are left to the charge of impersonal market forces, powerful government agents, or the state's bureaucratic apparatus; there is a comic contradiction in asserting pride while admitting that one lacks even potential responsibility for anything important. To the extent that a state lacks freedom for joint and collective action, its citizens will lack the possibility of responsibility of this kind. But if the citizen never touches the greatest human objects and, what is more, knows that such objects are not his to touch, then what sort of ideal citizen have we fashioned? A people that internalizes the principle that "individuals do small things and the state immense ones" will produce citizens with no ground for such pride (Tocqueville 1840/2000, 674). Without a positive element, the ideal falls flat.

If we are attracted to the ideal of the free citizen, then, we should hesitate to accept contemporary conceptualizations of such that include only non-domination. There are good grounds for thinking that Tocqueville's derivation of republicanism is more faithful to the ideal of the free citizen than one that conceptualizes this only in terms of non-domination; it provides positive grounds for pride and spirit that are not merely social and relative and that concern the power of republican social and political institutions to give us a more accurate grasp of our powers and potential. There is a great difference between a free citizen comfortable with responsibility for important matters and someone who, like a valorized associate professor who lacks any share in university governance, is merely safe and well administered. The ideal of the free citizen republicanism contains both a negative and a positive element, which the latter of these accounts leaves out.

Republicans should therefore consider the task of thinking through how such freedom can be conceptualized and instantiated in the contemporary context, if indeed we think that we and our fellows can be such citizens. Tocqueville provides evidence that republicanism can combine liberal, egalitarian, and participatory elements, and if his derivation is more faithful to the ideal that makes republicanism attractive in the first place, we ought to be attentive to it. However, Pettit's work should not be jettisoned. Rather, we ought to make 
greater use of it. Both his analysis of non-domination and that of group agency can and should be utilized and developed by future republicans, in order to provide a firmer analytical conceptualization of republican ideas; his work has the potential for providing a more precise understanding of its nature and value than has hitherto been available. Such a project, which developed republicanism in accordance with Tocqueville's vision but using the types of tools provided by Pettit, could perhaps not only bring Athens and Rome together in peace but also join their hands in a truly fruitful union.

\section{REFERENCES}

Berlin, Isaiah. 1958/2002. "Two Concepts of Liberty.” In Liberty: Incorporating Four Essays on Liberty, ed. Henry Hardy and Ian Harris, 166-217. Oxford: Oxford University Press.

Bronowski, Jacob, and Bruce Mazlish. 1960. The Western Intellectual Tradition: From Leonardo to Hegel. New York: Harper \& Row.

Jech, Alexander. 2013. “'Man Simply’: Excavating Tocqueville's Conception of Human Nature." Perspectives on Political Science 42:84-93.

— 2016. "Tocqueville, Pascal, and the Transcendent Horizon." American Political Thought 5:109-31.

Kahan, Alan. 2015. "Checks and Balances for Democratic Souls: Alexis de Tocqueville on Religion in Democratic Societies." American Political Thought 4:100-119.

King, Martin Luther, Jr. 1959/2001. The Measure of a Man. Repr., Minneapolis: Augsburg Fortress.

Lawler, Peter Augustine. 1993a. “The Restless Mind.” In Tocqueville's Defense of Human Liberty: Current Essays, ed. Peter Augustine Lawler and Joseph Alulis, 63-84. New York: Garland.

- 1993b. The Restless Mind: Alexis de Tocqueville on the Origin and Perpetuation of Human Liberty. Lanham, MD: Rowman \& Littlefield.

List, Christian, and Philip Pettit. 2011. Group Agency: The Possibility, Design, and Status of Corporate Agents. Oxford: Oxford University Press.

MacCallum, Gerald. 1967. "Negative and Positive Freedom." Philosophical Review 76:312-34.

Mahoney, Daniel J. 1993. “Tocqueville and Socialism.” In Tocqueville's Defense of Human Liberty: Current Essays, ed. Peter Augustine Lawler and Joseph Alulis, 177202. New York: Garland.

Manent, Pierre. 1996. Tocqueville and the Nature of Democracy. New York: Rowman \& Littlefield.

Markell, Patchen. 2008. “The Insufficiency of Non-Domination.” Political Theory 36: 9-36.

Marx, Karl. 1996. "The Eighteenth Brumaire of Louis Bonaparte.” In Marx: Later Political Writings, trans. and ed. Terrell Carver. Cambridge: Cambridge University Press.

Pettit, Philip. 1997. Republicanism: A Theory of Freedom and Government. Oxford: Oxford University Press. 
2012. On the People's Terms: A Republican Theory and Model of Democracy. Cambridge: Cambridge University Press.

Skinner, Quentin. 2006. “A Third Concept of Liberty.” In The Liberty Reader, ed. David Miller, 243-54. Boulder, CO: Paradigm.

- 2008. Hobbes and Republican Liberty. Cambridge: Cambridge University Press.

Taylor, Charles. 1985. "What's Wrong with Negative Liberty." In Philosophical Papers, vol. 2, Philosophy and the Human Sciences, 211-29. Cambridge: Cambridge University Press.

Tocqueville, Alexis de. 1840/2000. Democracy in America. Repr., Chicago: University of Chicago Press.

. 1856/1998. The Old Regime and the Revolution. Vol. 1. Ed. François Furet and Françoise Mélonio. Trans. Alan S. Kahan. Repr., Chicago: University of Chicago Press.

. 1968. "The Speech on the Right to Work." In Tocqueville and Beaumont on Social Reform, trans. and ed. Seymour Drescher. New York: Harper Torchbooks.

. 1985. Selected Letters on Politics and Society. Ed. Roger Boesche. Trans. Roger James Toupin and Roger Boesche. Berkeley: University of California Press.

- 1991. Euvres Complètes. Vol. 3. Paris: Éditions Gallimard.

. 2002. "Second Memoir on Pauperism." In The Tocqueville Reader: A Life in Letters and Politics, ed. Olivier Zunz and Alan S. Kahan. Oxford: Blackwell.

Weber, Max. 1905/2010. The Protestant Ethic and the Spirit of Capitalism. Repr., Oxford: Oxford University Press.

— 1946. "Bureaucracy." In From Max Weber: Essays in Sociology, 196-244. Oxford: Oxford University Press.

Wolin, Sheldon. 2003. Tocqueville between Two Worlds: The Making of a Political and Theoretical Life. Princeton, NJ: Princeton University Press.

Zuckert, Michael. 1993. "On Social State.” In Tocqueville's Defense of Human Liberty, ed. Peter Augustine Lawler and Joseph Alulis. New York: Garland. 